\title{
Wykonywanie uprawnień przedsiębiorcy jako pokrzywdzonego w procesie karnym
}

\section{Uwagi wstępne}

Przedmiotem niniejszego opracowania są zmiany dotyczące instytucji pokrzywdzonego zawarte w ustawie z dnia 27 września 2013 r. o zmianie ustawy - Kodeks postępowania karnego oraz niektórych innych ustaw i ustawy z dnia 20 lutego 2015 r. o zmianie ustawy - Kodeks karny oraz niektórych innych ustaw, które weszły w życie 1 lipca 2015 r. ${ }^{1}$ Ponadto w związku uchwaleniem przez Parlament Europejski i Radę dyrektywy nr 2012/29/EU z dnia 15 listopada 2012 r. regulującej normy minimalne w zakresie praw, wsparcia i ochrony ofiar przestępstw zastępującej decyzję ramową Rady 2001/220/ WsiSW podjęto działania w celu jej wdrożenia do polskiego systemu prawnego ${ }^{2}$. W wyniku prowadzonych prac dokonano wielu zmian w zakresie regulacji praw i obowiązków pokrzywdzonego, w szczególności na nowo zdefiniowano krąg podmiotów mogących być pokrzywdzonymi, stosując kryterium zdolności prawnej3. Część regulacji została przyjęta ustawą z dnia 28 listopada 2014 r. o ochronie i pomocy dla pokrzywdzonego i świadka ${ }^{4}$. Natomiast ustawą z dnia 9 października 2015 r. o zmianie ustawy Kodeks karny oraz niektórych innych ustaw ${ }^{5}$, która weszła w życie 13 lutego 2016 r., wprowadzono nowe istotne uprawnienie pokrzywdzonego o charakterze gwarancyjnym, zgodnie z którym na wniosek pokrzywdzonego wydawane jest potwierdzenie złożenia formalnego zawiadomienia o popełnieniu przestępstwa.

1 Ustawa z dnia 27 września 2013 r. o zmianie ustawy - Kodeks postępowania karnego oraz niektórych innych ustaw (Dz.U. poz. 1247) oraz ustawa z dnia 20 lutego 2015 r. o zmianie ustawy - Kodeks karny oraz niektórych innych ustaw (Dz.U. poz. 396).

2 Dz.Urz. UE L 315 z dnia 14 listopada 2012 r., s. 57-73.

3 Uzasadnienie projektu ustawy z dnia 5 czerwca 2012 r. o zmianie ustawy - Kodeks karny, Kodeks postępowania karnego i niektórych innych ustaw, http://bip.ms.gov.pl/pl/projekty-aktow-prawnych/prawo-karne/, s. 38 [dostęp: 30.06.2016].

4 Dz.U. 2015 poz. 21.

5 Dz.U. 2015 poz. 1855. 
Celem niniejszego opracowania jest ukazanie kierunku dokonywanych zmian i ich ocena, ze szczególnym uwzględnieniem pozycji przedsiębiorcy jako pokrzywdzonego przed i po nowelizacji z dnia 27 września 2013 r. oraz z dnia 20 lutego 2015 r., które wprowadziły nowy model procedury karnej. Ponadto w ograniczonym zakresie zostanie poruszone zagadnienie skuteczności doręczeń pism procesowych pokrzywdzonemu będącym przedsiębiorcą jako praktycznego instrumentu zabezpieczającego prawa pokrzywdzonego.

\section{Definicja pokrzywdzonego}

W myśl art. 49 ustawy Kodeks postępowania karnego z dnia 6 czerwca 1997 r. ${ }^{6}$ pokrzywdzonym była osoba fizyczna lub prawna, której dobro prawne zostało bezpośrednio naruszone lub zagrożone przez przestępstwo. Pokrzywdzonym mogła być także instytucja państwowa, samorządowa lub społeczna, choćby nie miała osobowości prawnej Do uznania, że dany podmiot korzysta ze statusu pokrzywdzonego, nie była wymagana decyzja procesowa ${ }^{8}$. Z definicji zawartej w art. 49 k.p.k. wynikało wprost, że status pokrzywdzonego mógł uzyskać określony krąg podmiotów, które spełniały łącznie dwa kryteria. Po pierwsze, można było zaliczyć dany podmiot do kategorii osób fizycznych lub prawnych, a także instytucji państwowych, samorządowych lub społecznych, choćby nie miały osobowości prawnej. Po drugie, dobro prawne ${ }^{9}$ tego podmiotu zostało bez-

6 Dz.U. nr 89 poz. 555 z późn. zm. z dnia 1 lipca 2007 r.

7 Art. 49 k.p.k był dwukrotnie nowelizowany. Po raz pierwszy ustawą z dnia 13 kwietnia 2007 r. (Dz.U. nr 89 poz.589) o Państwowej Inspekcji Pracy zgodnie z art. 90 tej ustawy z dniem 1 lipca 2007 r. dodano § 3a, według którego w sprawach o przestępstwa przeciwko prawom osób wykonujących pracę zarobkową, o których mowa w art. 218-221 oraz w art. 225 k.k., organy Państwowej Inspekcji Pracy mogą wykonywać prawa pokrzywdzonego, jeżeli w zakresie swego działania ujawniły przestępstwo lub wystąpiły o wszczęcie postępowania. Druga nowelizacja art. 49 k.p.k. nastąpiła ustawą z dnia 27 września 2013 r. o zmianie ustawy - Kodeks postępowania karnego oraz niektórych innych ustaw (Dz.U. poz. 1247), która weszła w życie 1 lipca $2015 \mathrm{r}$.

8 K. Dudka, Wplyw prawa karnego materialnego na ustawowq definicje pokrzywdzonego, [w:] Wspótzależność prawa karnego procesowego i materialnego, red. G. Arytmiak, Z. Ćwiąkalski, Warszawa 2009, s. 145.

$9 \mathrm{~W}$ literaturze szeroko komentowane jest pojęcie naruszenia dobra prawnego pokrzywdzonego. Przed przyznaniem statusu pokrzywdzonego w rozumieniu art. $49 \S 1$ k.p.k. należy prawidłowo rozpoznać indywidualny przedmiot ochrony analizowanej normy karnej. Zapatrywania te zostały wyrażone w uchwale SN z 15.09.1999 r., I KZP 26/99 (OSNKW 1999, z.11-12, poz. 69), iż „Krąg pokrzywdzonych w rozumieniu art. 49 § 1 k.p.k. ograniczony jest zespołem znamion czynu będącego przedmiotem postępowania oraz czynów współukaranych". W doktrynie oprócz materialnej definicji pokrzywdzonego można wyróżnić zwolenników definicji procesowej, którzy wskazują również na zespół uprawnień procesowych związanych ze statusem pokrzywdzonego. Cf.M. Cieślak, Polska procedura karna. Podstawowezatożenia teoretyczne, Warszawa1984, s. 36-37. 
pośrednio naruszone lub zagrożone przez przestępstwo ${ }^{10}$. Pierwsze kryterium, stosując wykładnię literalną, wyłączało z kręgu podmiotów pokrzywdzonych ułomne osoby prawne (m.in. spółki osobowe w rozumieniu art. 8 k.s.h. oraz spółki kapitałowe w organizacji w rozumieniu art. 11 k.s.h.). Definicja ułomnych (niepełnych) osób prawnych jako jednostek organizacyjnych niebędącymi osobami prawnymi, którym jednak ustawa przyznaje zdolność prawną i do których stosuje się odpowiednio przepisy o osobach prawnych, została zawarta w Kodeksie cywilnym. Należy również przywołać treść art. $33^{1}$ k.c., który wskazywał, że do jednostek organizacyjnych niebędącymi osobami prawnymi, którym ustawa przyznaje zdolność prawną, stosuje się odpowiednio przepisy o osobach prawnych, mimo że podmioty te osobami prawnymi nie są. Tym samym ustawodawca expressis verbis wskazywał, że ułomne osoby prawne w rozumieniu art. 49 k.p.k. nie mogą korzystać ze statusu pokrzywdzonego.

\section{Definicja przedsiębiorcy}

Nasuwa się zatem pytanie, czy definicja pokrzywdzonego z art. 49 k.p.k. wyłącza z kręgu pokrzywdzonych przedsiębiorcę. W tym zakresie należy odnieść się do definicji przedsiębiorcy zawartej w art. $43^{1}$ k.c., która stosowana jest na gruncie prawa prywatnego, jednakże podnosi się, że powyższa definicja powinna być również stosowana w zakresie prawa publicznego z dwóch względów: przejrzystości, tj. wyeliminowania mnogości stosowanych definicji11, oraz gwarancyjności - powinna występować jednolitość w zabezpieczeniu praw podmiotów uznawanych za przedsiębiorcę. Zgodnie $\mathrm{z}$ art. $43^{1} \mathrm{k}$.c. przedsiębiorcą jest osoba fizyczna, osoba prawna i jednostka organizacyjna, o której mowa $\mathrm{w}$ art. $33^{1} \S 1$ k.c., prowadząca we własnym imieniu działalność gospodarczą lub zawodową. Zestawienie powyższej definicji z definicją zawartą w art. 49 k.p.k. sprzed nowelizacji ustawy z dnia 27 września 2013 r. o zmianie ustawy - Kodeks postępowania karnego oraz niektórych innych ustaw uściślała, że pokrzywdzonym mógł być przedsiębiorca, który był osobą fizyczną lub osobą prawną. Poza tym zakresem znajdowali się przedsiębiorcy będący ułomnymi osobami prawnymi, czyli wszystkie spółki osobowe w rozumieniu art. 8 k.s.h., to znaczy spółki jawne, partnerskie, komandytowe, komandytowo-akcyjne oraz spółki kapitałowe w organizacji w rozumieniu art. 11 k.s.h. Podmiotów tych również nie można było uznać za pokrzywdzonych w rozumieniu art. 49 zd. 2

10 Status pokrzywdzonego może uzyskać wyłącznie ten podmiot, którego dobro prawne zostało wprost naruszone działaniem przestępnym, nie zaś pośrednio godziło w inne dobra prawne. Cf. W. Daszkiewicz, Proces karny. Częśc ogólna, Warszawa 1994, s. 189; uchwała SN z dnia 12 maja 1993 r., I KZP 6/93, LEX 20583; uchwała SN z dnia 21 października 2003 r., I KZP 29/03, LEX 81320.

11 W. Jasiński, Przedsiębiorca jako pokrzywdzony w procesie karnym na tle art. 49 \$ 1 i 2 k.p.c., „Państwo i Prawo" 2012, nr 7, s. 79-80. 
k.p.k., czyli jako instytucji państwowych, samorządowych lub społecznych, choćby nie miały osobowości prawnej, z wyjątkiem organizacji społecznych prowadzących działalność gospodarczą.

\section{Nowelizacja art. 49 k.p.k. w świetle ustawy z dnia 27 września 2013 r. o zmianie ustawy - Kodeks postępowania karnego oraz niektórych innych ustaw i jej geneza}

Problem braku możliwości uznania ułomnych osób prawnych za pokrzywdzonego został w literaturze określony jako następstwo uchybienia w zakresie nowelizacji12. Wprowadzenie art. $33^{1} \S 1$ k.c. zawierającego definicję ułomnych osób prawnych nie doprowadziło do zmiany art. 1 k.c., który wzorem tradycji rzymskiej zawiera dychotomiczny podział podmiotów w stosunkach cywilnoprawnych na osoby fizyczne i prawne ${ }^{13}$. Ustawodawca nie podjął próby zmodyfikowania art. 1 k.c., pozostając przy dotychczasowym - dualistycznym - podziale podmiotów stosunków cywilnoprawnych, a jednocześnie uznał, że ułomne osoby prawne zawierają się w pojęciu osób prawnych, czemu ustawodawca dał wyraz w art. $33^{1}$ k.c., wskazując, że do jednostek organizacyjnych niebędącymi osobami prawnymi, którym ustawa przyznaje zdolność prawną stosuje się odpowiednio przepisy o osobach prawnych, mimo że podmioty te osobami prawnymi nie są.

Powyższe zapatrywania znalazły odzwierciedlenie w postanowieniu Sądu Najwyższego z dnia 21 lipca 2011 r., które wskazuje, że spółka jawna może występować w postępowaniu karnym w charakterze pokrzywdzonego, gdyż stosuje się wobec niej odpowiednio przepisy o osobach prawnych (art. $33^{1}$ k.c.) $)^{14}$. Powyższe rozstrzygnięcie pozwoliło na przyznanie przedsiębiorcy niebędącemu osobą fizyczną lub prawną prawa do działania $\mathrm{w}$ postępowaniu przygotowawczym w charakterze strony jako pokrzywdzony pomimo braku stosownej regulacji w art. 49 k.p.k.

Problem wykluczenia ułomnych osób prawnych został rozwiązany na gruncie nowelizacji ustawy z dnia 27 września 2013 r. o zmianie ustawy - Kodeks postępowania karnego

12 W.J. Katner, Podwójna czy potrójna podmiotowość w prawie cywilnym, w: Rozprawy prawnicze. Ksiega pamiątkowa Profesora Maksymiliana Pazdana, red. L. Ogiegło, W. Popiołek, M. Szpunar, Kraków 2005, s. 1027; A. Doliwa, Prawo cywilne - częśc ogólna, Warszawa 2004, s. 181.

$13 \mathrm{~W}$ polskiej doktrynie zwolennikiem teorii trzech typów podmiotowości oraz twórca teorii ułomnych osób prawnych był Aleksander Wolter. Wyróżniał on oprócz osób fizycznych i osób prawnych, jak określa art. 33 k.c., jednostki organizacyjne, którym przepisy nie przyznają osobowości prawnej, jednakże przysługują im atrybuty osoby prawnej i powinny być one zaliczane do podmiotów stosunków cywilnoprawnych. A. Wolter, J. Ignatowicz, K. Stefaniuk, Prawo cywilne. Zarys części ogólnej, Warszawa 2001, s. 230.

14 Postanowienie SN z dnia 21 lipca 2011 r., I KZP 7/11, LEX nr 852215; S.Durczak-Żochowska, Glosa do postanowienia SN z dnia 21 lipca 2011 r., I KZP 7/11, „Państwo i Prawo” 2012, nr 9, s. 136-142; T. Demendecki, Glosa do postanowienia SNz dnia 21 lipca 2011 r., I KZP 7/11, „Glosa” 2012, nr 3, s. 60-68. 
oraz niektórych innych ustaw, która weszła w życie 1 lipca 2015 r. Komisja Kodyfikacyjna, przedstawiając projekt art. 49 k.p.k., zwróciła uwagę, że definicja pokrzywdzonego w dotychczasowym kształcie nie odnosiła się do zmian jakie nastąpiły w zakresie Kodeksu cywilnego oraz Kodeksu karnego skarbowego. W szczególności nie uwzględniono faktu, że stroną stosunku prawnego oprócz osób fizycznych lub prawnych mogą być jednostki organizacyjne niebędące osobami prawnymi, którym ustawa przyznaje zdolność prawną. Przede wszystkim należy zauważyć, że Kodeks karny skarbowy nie zawiera definicji pokrzywdzonego, na której treść powołuje się Komisja Kodyfikacyjna ${ }^{15}$. Przepis art. 113 $\S 2$ pkt 1 k.k.s. wyłącza zastosowanie w postępowaniach o przestępstwa i wykroczenia skarbowe przepisów k.p.k. dotyczących pokrzywdzonego i mediacji.

Komisja Kodyfikacyjna, dokonując ujednolicenia definicji art. 49 k.p.k., zastosowała kryterium zdolności prawnej, zachowując jednocześnie kategorię instytucji państwowych oraz samorządowych. W pierwotnie proponowanej wersji art. 49 k.p.k. instytucje państwowe, społeczne i samorządowe zostały wykreślone, co w literaturze było krytykowane z uwagi na fakt, że wykreślenie to eliminowało podmioty, które są jednostkami organizacyjnymi, ale nie miały zdolności prawnej. Ostatecznie ustawodawca wprowadził art. 49 § 2 k.p.k. o treści, że pokrzywdzonym może być także niemająca osobowości prawnej inna jednostka organizacyjna, której odrębne przepisy przyznają zdolność prawną, oraz pozostawił kategorię instytucji państwowych oraz samorządowych.

Dokonując powyższych zmian, ustawodawca powinien też dostosować treść art. 51 $\S 1$ k.p.k. do katalogu podmiotów, które mogą działać za pokrzywdzonego w procesie karnym. Zgodnie z art. 51 § 1 k.p.k. za pokrzywdzonego, który nie jest osobą fizyczną, czynności procesowych dokonuje organ uprawniony do działania w jego imieniu. W przypadku ułomnych osób prawnych nie zawsze mamy do czynienia z organami, które działają w ich imieniu. Ułomne osoby prawne reprezentowane są przez swoich członków, a w przypadku spółek osobowych są to wspólnicy spółki jawnej, partnerzy lub komplementariusze. W postanowieniu z dnia 7 maja 2014 r. Sąd Najwyższy stwierdził, że art. $51 \S 1$ k.p.k. ma charakter blankietowy, gdyż nie wskazuje organów uprawnionych do reprezentacji pokrzywdzonego i w odniesieniu do każdego pokrzywdzonego, który nie jest osobą fizyczną, należy dokonać powyższych ustaleń w odpowiednich przepisach ustaw i wynikających z nich regulacjach ${ }^{16}$. Pomimo nowelizacji obecna treść art. 51 k.p.k. nie uwzględnia, że ułomne osoby prawne są reprezentowane w sposób odmienny niż osoby prawne.

$\mathrm{Na}$ marginesie należy zauważyć, że ustawodawca posługuje się odmienną definicją pokrzywdzonego w Kodeksie postępowania w sprawach o wykroczenia. Art. 25 k.p.o.w.

15 W. Jasiński, Przedsiębiorca jako pokrzywdzony w procesie karnym na tle art. 49 par 1 i 2 kpc, „Państwo i Prawo" 2012, nr 7, s. 85.

16 Postanowienie SN z dnia 7 maja 2014 r., IV KK 364/13, http:/www.sn.pl/sites/orzecznictwo/ Orzeczenia3/IV\%20KK\%20364-13.pdf [dostęp: 30.06.2016]. 
zawiera szeroką formułę pokrzywdzonego jako tego, którego dobro prawne zostało bezpośrednio naruszone lub zagrożone przez wykroczenie, nie odnosząc się do kryterium zdolności prawnej. Określenie „ten” obejmuje wszystkie podmioty - osobę fizyczną, osobę prawną oraz inne jednostki organizacyjne ${ }^{17}$. Ustawodawca w k.p.o.w. nie posługuje się dodatkowymi określeniami zdefiniowanymi na gruncie Kodeksu cywilnego, aby wskazać, który podmiot może korzystać ze statusu pokrzywdzonego.

\section{Uprawnienia pokrzywdzonego jako przedsiębiorcy}

Analizując treść kolejnych przepisów Kodeksu postępowania karnego, należy zauważyć, że ustawodawca podobnie reguluje uprawnienia pokrzywdzonego, co oznacza, iż zakresy uprawnień pokrzywdzonego przedsiębiorcy, jak i pokrzywdzonego, który przedsiębiorcą nie jest, nie różnią się, chociaż znajdziemy przepisy szczególne kierowane wyłącznie do przedsiębiorców w zakresie trybu doręczenia pism procesowych czy reprezentacji przedsiębiorcy. Tym samym należałoby przedstawić nowe uprawnienia pokrzywdzonego zgodnie z ustawą z dnia 27 września 2013 r. o zmianie ustawy - Kodeks postępowania karnego oraz niektórych innych ustaw i ustawą z dnia 20 lutego 2015 r. o zmianie ustawy - Kodeks karny oraz niektórych innych ustaw, które weszły w życie dnia 1 lipca 2015 r.

Głównym postulatem wprowadzanych zmian było określenie zakresu pouczenia pokrzywdzonego w postępowaniu przygotowawczym celem zapewnienia równego traktowania stron w postępowaniu karnym. Ustawodawca wskazał nie tylko poszczególne uprawnienia pokrzywdzonego, które powinny znaleźć się w pouczeniu, ale dążył również do określenia form i sposobów pouczenia zgodnie z dyrektywą Parlamentu Europejskiego i Rady 2012/13/UE z dnia 22 maja 2012 r. w sprawie prawa do informacji w postępowaniu karnym, która ostatecznie została implementowana do polskiego systemu prawnego.

Organy postępowania przygotowawczego powinny pouczyć pokrzywdzonego, że na tym etapie postępowania przysługuje mu status strony. Jako strona postępowania pokrzywdzony może, jeżeli taka jest jego wola, czynnie uczestniczyć w postępowaniu poprzez składanie wniosków o dokonanie czynności śledztwa lub dochodzenia (art.315-318 k.p.k.). Ponadto należy pouczyć pokrzywdzonego pod jakimi warunkami może uzyskać status strony w postępowaniu sądowym (art. 51 i 52 k.p.k.) oraz o prawie do uzyskania pełnomocnika zarówno w postępowaniu przygotowawczym, jak i sądowym. Uzyskanie pełnomocnika z urzędu nie jest ograniczone cenzusem majątkowym (art. 87a § 3 k.p.k.), jednak obowiązuje tu reguła odpowiedzialności za wynik postępowania. Oskarżyciel posiłkowy w zależności od wyniku procesu może być obciążony kosztami ustanowienia pełnomocnika w postępowaniu sądowym, o czym musi być wyraźnie pouczony.

17 T. Grzegorczyk, Kodeks postępowania w sprawach o wykroczenia. Komentarz, Warszawa 2012, s. 117-118. 
W istocie w postępowaniu przygotowawczym pokrzywdzony może skorzystać z prawa ubogich w sytuacji spełnienia przesłanek zawartych w art. 78 k.p.k. Pokrzywdzonemu przysługuje prawo do korzystania z pomocy wybranego przez siebie pełnomocnika, którym może być adwokat lub radca prawny. Jeżeli pokrzywdzony wykaże, że nie stać go na pełnomocnika, sąd może wyznaczyć pełnomocnika z urzędu (art. 78 § 1, art. 87 $\S 1$ i 2 , art. 88 k.p.k.). Powyższa regulacja nie będzie miała zastosowania w przypadku przedsiębiorcy będącego osobą prawną lub ułomną osobą prawną, gdyż w danym przypadku zastosowanie mają przepisy postępowania cywilnego w zakresie pełnomocnika z urzędu. Zgodnie z art. 117 § 3 k.p.c. osoba prawna lub inna jednostka organizacyjna, której ustawa przyznaje zdolność sądową, niezwolniona przez sąd od kosztów sądowych, może domagać się ustanowienia adwokata lub radcy prawnego, jeżeli wykaże, że nie ma dostatecznych środków na poniesienie kosztów wynagrodzenia adwokata lub radcy prawnego. Pouczenie to powinno więc zostać zmodyfikowane w sytuacji, gdy pokrzywdzonym będzie osoba prawna lub ułomna osoba prawna.

Pokrzywdzonemu przysługuje prawo do złożenia zażalenia na postanowienie o odmowie wszczęcia lub umorzeniu śledztwa lub dochodzenia oraz zażalenia na bezczynność, jeżeli w ciągu 6 tygodni od złożenia przez pokrzywdzonego zawiadomienia o przestępstwie nie został on powiadomiony o wszczęciu albo odmowie wszczęcia śledztwa lub dochodzenia (art. 306 § 1, 1a, 3 k.p.k.). Pokrzywdzony ma prawo do złożenia wniosku o skierowanie sprawy do postępowania mediacyjnego $\mathrm{w}$ celu pogodzenia się z podejrzanym (art. 23a k.p.k.) oraz prawo do złożenia wniosku o umorzenie postępowania w określonych enumeratywnie typach przestępstw - wówczas gdy pojedna się ze sprawcą, a sprawca naprawi szkodę i zadośćuczyni krzywdzie. Pouczenie to ma ograniczać konieczność rozpoznawania spraw w toku pełnego kontradyktoryjnego procesu.

Przedstawione wyżej uprawnienia pokrzywdzonego zostały uporządkowane w formie formularza. Od 8 kwietnia 2015 r. formularz zawiera wzmiankę o nowych formach i sposobach ochrony pokrzywdzonego m.in. o: możliwościach naprawienia szkody przez oskarżonego lub uzyskania kompensaty państwowej, dostępie do pomocy prawnej, możliwości wydania europejskiego nakazu ochrony, organizacjach wsparcia pokrzywdzonych, możliwości zwrotu kosztów poniesionych w związku z udziałem w postępowaniu.

\section{Doręczenia wezwań i pism procesowych przedsiębiorcy}

Osobno należy przedstawić problem doręczeń wezwań i pism procesowych przedsiębiorcy. Pokrzywdzony musi zostać pouczony o zasadach doręczania wezwań oraz zasadach zawiadamiania o terminach rozpraw oraz posiedzeń zgodnie z art. 138 i 139 k.p.k. W sytuacji gdy pokrzywdzonym jest przedsiębiorca, który jest jednocześnie ułomną osobą prawną, pouczenie powinno być kierowane do członków tego podmiotu, wspólników spółki jawnej, partnerów lub komplementariuszy, a w przypadku osób prawnych - do 
jego organów. Przesyłki dla adresata niebędącego osobą fizyczną albo dla obrońcy lub pełnomocnika doręcza się w biurze adresata osobie tam zatrudnionej (art.134 § 3 k.p.k), która nie musi posiadać upoważnienia do odbioru pism - kryterium decydującym jest fakt zatrudnienia u adresata. Pod pojęciem „biuro adresata” należy rozumieć kancelarię pełnomocnika lub adres siedziby pokrzywdzonego, którym nie musi być adres podany $\mathrm{w}$ rejestrze ${ }^{18}$. Powyższe rozwiązania różnią się od przepisów k.p.c., gdzie zawarto szczególną procedurę doręczeń dla przedsiębiorców i wspólników spółek handlowych. Zgodnie $\mathrm{z}$ art. 133 § 2a k.p.c. pisma procesowe dla przedsiębiorców i wspólników spółek handlowych, wpisanych do rejestru sądowego na podstawie odrębnych przepisów, doręcza się na adres podany w rejestrze, chyba że strona wskazała inny adres do doręczeń. Jeżeli ostatni wpisany adres został wykreślony jako niezgodny z rzeczywistym stanem i nie zgłoszono wniosku o wpis nowego adresu, adres wykreślony uważany jest za adres podany w rejestrze. Tym samym w postępowaniu cywilnym pisma dla przedsiębiorców, którzy są osobami fizycznymi, doręcza się zgodnie z zasadami określonymi w art. 133 § 1 k.p.c., czyli w mieszkaniu, miejscu pracy lub tam, gdzie adresata się zastanie ${ }^{19}$. W razie niemożności doręczenia w sposób przewidziany w przepisach k.p.c. z uwagi na nieujawnienie w rejestrze albo w ewidencji zmiany adresu, a w przypadku osób fizycznych miejsca zamieszkania i adresu przesyłki pozostawia się w aktach sprawy ze skutkiem doręczenia, chyba że nowe miejsce zamieszkania i adres są sądowi znane.

W tym zakresie kluczowa wydaje się zmiana zaproponowana ustawą z dnia 9 października 2015 r. o zmianie ustawy Kodeks karny oraz niektórych innych ustaw ${ }^{20}$, która weszła w życie 13 lutego 2016 r. Zgodnie z art.304b k.p.k. na wniosek pokrzywdzonego składającego zawiadomienie o przestępstwie organ procesowy wydaje mu potwierdzenie złożenia zawiadomienia, zawierające datę i miejsce jego przyjęcia, wskazanie organu przyjmującego wraz z danymi do kontaktu, sygnaturę sprawy, dane określające tożsamość pokrzywdzonego, czas i miejsce popełnienia czynu, którego dotyczy zawiadomienie, oraz zwięzły opis czynu i wyrządzonej szkody. O prawie tym należy pokrzywdzonego pouczyć. Pisemne zawiadomienie o popełnieniu przestępstwa określa nie tylko elementy popełnienia czynu, ale też precyzuje tożsamość pokrzywdzonego poprzez podanie adresu do korespondencji, co w toku dalszego postępowania pozwala organom procesowym na podjęcie dalszych czynności. Skuteczne doręczenie wezwań lub pism procesowych zarówno na etapie postępowania przygotowawczego, jak i sądowego stanowi istotny instrument zabezpieczający prawa pokrzywdzonego, gdyż dopiero z chwilą dokonania skutecznego doręczenia pism pokrzywdzony może w pełni realizować przysługujące mu prawa. Wprowadzona zmiana koresponduje z treścią art. 139 k.p.k., zgodnie z którym

18 T. Grzegorczyk, J. Tylman, Polskie posteppowanie karne, Warszawa 2011, s. 445.

19 Wyrok SA w Poznaniu z dnia 19 grudnia 2012 r., I Aca 1046/12, Lex nr 1264383; postanowienie SN z dnia 10 marca 2006 r., IV CK 287/05, Lex nr 398357.

20 Dz.U. poz. 1855. 
strona, nie podając nowego adresu, zmienia miejsce zamieszkania lub nie przebywa pod wskazanym przez siebie adresem, także $\mathrm{z}$ powodu pozbawienia wolności w innej sprawie, a pismo wysłane pod ten adres uważa się za doręczone. Oznacza to, że po przyjęciu zawiadomienia o popełnieniu przestępstwa organ procesowy kieruje korespondencję na adres wskazany przez pokrzywdzonego. Jeżeli adres ten uległ zmianie, pokrzywdzony powinien o tym poinformować organy procesowe. Natomiast gdy w toku postępowania zostaną ustaleni inni pokrzywdzeni ograny procesowe kierują do nich zawiadomienie o przysługujących im uprawnieniach (a contrario art. $131 \S 1$ k.p.k.). Ustawodawca nie wskazuje, na jaki adres przedsiębiorcy należy skierować korespondencję - czy na adres siedziby pokrzywdzonego, adres rejestrowy, czy może adres konkretnego oddziału. Za uzasadnioną praktykę należałby uznać kierowanie korespondencji na wszystkie ustalone adresy pokrzywdzonego, jeżeli są one różne, gdyż w ten sposób organy procesowe korzystają z instrumentów prawnych (w tym wypadku właściwych przepisów o trybie doręczeń), które chronią prawa pokrzywdzonego. Ustawodawca pozostawił jeszcze jedną możliwość zawiadomienia pokrzywdzonych o przysługujących im prawach - poprzez ogłoszenie w prasie, radiu lub telewizji. Powyższe zawiadomienie stanowi wyjątek i może być stosowane wyłącznie w sytuacji, gdy indywidualne zawiadomienie o przysługujących pokrzywdzonym uprawnieniach spowodowałoby poważne utrudnienia w prowadzeniu postępowania.

\section{Przedsiębiorca będący spółką cywilną jako pokrzywdzony}

Zgodnie z art. 860 § 1 k.c. poprzez umowę spółki wspólnicy zobowiązują się dążyć do osiągnięcia wspólnego celu gospodarczego przez działanie w sposób oznaczony, w szczególności przez wniesienie wkładów. Umowa spółki cywilnej musi być zawarta pomiędzy co najmniej dwiema osobami fizycznymi lub prawnymi. Wspólnicy spółki cywilnej podlegają wpisowi do Centralnej Ewidencji i Informacji o Działalności Gospodarczej (CEIDG). Natomiast sama spółka cywilna nie ma osobowości prawnej i nie podlega rejestracji w Krajowym Rejestrze Sądowym. Za zobowiązania spółki wspólnicy odpowiadają solidarnie swym majątkiem wspólnym oraz każdy ze wspólników z osobna majątkiem osobistym - bez żadnych ograniczeń. Przedsiębiorcą w rozumieniu art. $43^{1}$ k.c. jest wspólnik spółki cywilnej. Sytuacja prawna spółki cywilnej jest całkowicie odmienna od spółki jawnej, która ma zdolność prawną i zdolność do czynności prawnych, a tym samym odpowiedzialność wspólników kształtuje się w sposób odmienny niż w spółce cywilnej. Odpowiedzialność wspólników spółki jawnej jest odpowiedzialnością solidarną i subsydiarną zgodnie z art. 22 § 2 k.s.h. Spółka jawna nie posiada osobowości prawnej i zaliczana jest do jednostek organizacyjnych nieposiadających osobowości prawnej, której ustawa przyznaje zdolność prawną. 
Powyższa analiza nasuwa pytanie, czy przedsiębiorca będący spółką cywilną może korzystać ze statusu pokrzywdzonego, a także czy status ten podlega przekazaniu wraz z przekształceniem spółki cywilnej w inną formę prawną - tu na przykładzie spółki jawnej?

Problem ten został rozpatrzony przez Sąd Apelacyjny w Katowicach postanowieniem z dnia 2 lipca 2008 r. ${ }^{21}$ Sąd wskazał, że:

[...] niedopuszczalnym i błędnym jest przyjęcie, iż wraz z przekształceniem się spółki cywilnej w spółkę jawną nastąpiło „przekazanie statusu pokrzywdzonego” z pierwotnie uprawnionych osób na nowo powstały podmiot prawny, bowiem tego rodzaju „zbycie”, czy też przejście uprawnień w świetle przepisu art. 860 i nast. k.c. oraz przepisu art. $26 \S 4-6$ k.s.h., jak również przepisów postępowania karnego, nie jest możliwe. W świetle przepisów postępowania karnego, pokrzywdzonym jest podmiot, którym może być osoba fizyczna lub prawna, a nie przedmiot (mienie), co powoduje, iż status pokrzywdzonego nie mógł zostać przekazany w drodze przekształcenia się spółki cywilnej w trybie przepisu art. 26 § k.s.h. w spółkę jawną.

Powyższe rozważania mają również zastosowanie w obecnym stanie prawnym po nowelizacji z dnia 27 września 2013 r. wobec zmiany definicji pokrzywdzonego, którym może być także nieposiadająca osobowości prawnej inna jednostka organizacyjna mająca na gruncie odrębnych przepisów zdolność prawną. Komisja Kodyfikacyjna w uzasadnienie projektu ustawy z dnia 5 czerwca 2012 r. o zmianie ustawy - Kodeks karny, Kodeks postępowania karnego i niektórych innych ustaw podkreśliła, że przy ujednoliceniu definicji art. 49 k.p.k. zastosowała kryterium zdolności prawnej, zachowując jednocześnie kategorię instytucji państwowych oraz samorządowych ${ }^{22}$. Zatem nie jest dopuszczalne „przekazanie statusu pokrzywdzonego” w świetle przepisów postępowania karnego.

Odnosząc się do zagadnienia możliwości korzystania przez przedsiębiorcę będącego spółką cywilną ze statusu pokrzywdzonego, należy zwrócić uwagę na dwa aspekty tego problemu. Definicja pokrzywdzonego, jak wskazuje M. Cieślak, ma zarówno charakter materialny, jak i procesowy ze względu na uprawnienia procesowe przysługujące pokrzywdzonemu ${ }^{23}$. Określając krąg podmiotów, które mogą korzystać ze statusu pokrzywdzonego, należy najpierw zdefiniować zespół znamion czynu będącego przedmiotem postępowania oraz czynów współukaranych, a następnie uściślić, który podmiot

21 Postanowienie SA w Katowicach z dnia 2 lipca 2008 r., sygn. akt II AKz 476/08, LEX nr 447111.

22 Uzasadnienie projektu ustawy z dnia 5 czerwca 2012 r. o zmianie ustawy - Kodeks karny, Kodeks postępowania karnego i niektórych innych ustaw, http://bip.ms.gov.p1/pl/projekty-aktow-prawnych/prawo-karne/, s. 38 [dostęp: 30.06.2016].

23 M. Cieślak, Polska procedura karna. Podstawowe zatożenia teoretyczne, Warszawa 1984, s. 36. 
może skorzystać ze statusu pokrzywdzonego ${ }^{24}$. W sytuacji gdy mamy do czynienia ze spółką cywilną, trudno określić podmiot korzystający ze statusu pokrzywdzonego, gdyż spółka cywilna nie została wyposażona w osobowość prawną. $Z$ podmiotowość prawnej korzystają wyłącznie wspólnicy spółki. Z drugiej strony wspólnicy nie tworzą majątku, który stanowi ich odrębną własność, wręcz przeciwnie - na mocy umowy spółki cywilnej powstaje majątek wspólny wspólników, który jest niepodzielny i przysługuje łącznie wszystkim wspólnikom. Przestępstwa przeciwko spółce cywilnej będą głównie godzić w kapitał spółki cywilnej, pośrednio w majątek wspólników, spadkobierców wspólników spółki cywilnej czy majątek współmałżonka wspólnika opartego na zasadach małżeńskiej wspólności majątkowej. W razie rozwiązania umowy spółki cywilnej ustaje wspólność, majątek spółki staje się współwłasnością w częściach ułamkowych i w powyższej sytuacji status pokrzywdzonego przysługuje byłym wspólnikom lub spadkobiercom ${ }^{25}$. Natomiast w czasie trwania umowy spółki cywilnej w oparciu o treść art. 49 k.p.k oraz art. 860 § 1 k.c. i nast. należy uznać, że wspólnicy spółki cywilnej korzystają ze statusu pokrzywdzonego zarówno w sytuacji, gdy wspólnikami są osoby fizyczne, osoby prawne czy też niemająca osobowości prawnej inna jednostka organizacyjna, której odrębne przepisy przyznają zdolność prawną.

\section{Podsumowanie}

Analiza zagadnienia wykonywania uprawnień przedsiębiorcy jako pokrzywdzonego w procesie karnym nasuwa następujące wnioski. Kodeks postępowania karnego, w przeciwieństwie do Kodeksu postępowania cywilnego, nie nadał przedsiębiorcy szczególnych uprawnień czy obowiązków. Można jednak oczekiwać, że sytuacja ta ulegnie zmianie, gdyż ochrona praw przedsiębiorcy - tu na przykładzie pokrzywdzonego - wymaga redefinicji. Nowelizacja Kodeksu postępowania karnego z dnia 27 września 2013 r. oraz z 20 lutego 2015 r. ostatecznie w kręgu osób pokrzywdzonych ujęła ułomne (niepełne) osoby prawne, zachowując jednocześnie kategorię instytucji państwowych oraz samorządowych. Wprowadzona zmiana oznacza, że przedsiębiorca zarówno będący osobą fizyczną, jak i prawną oraz ułomną osobą prawną może korzystać ze statusu pokrzywdzonego. Ponadto ustawodawca na nowo określił sytuację prawną pokrzywdzonego poprzez umocnienie jego pozycji jako strony postępowania przygotowawczego. Ustawodawca, kierując się zasadą równego traktowania stron postępowania, stworzył katalog uprawnień i obowiązków pokrzywdzonego, które w postaci formularza są kierowane do pokrzywdzonego. Niestety formularz ten nie jest przystosowany do istniejącego katalogu pokrzywdzonych i nie uwzględnia specyfiki pokrzywdzonego przedsiębiorcy.

24 Uchwała SN z dnia 1 grudnia 1999 r., I KZP 26/99, LEX 38571.

25 A. Piaczyńska, Przestępne przywtaszczenie sktadnika objętego wspólnym majątkiem wspólników, „Prokuratura i Prawo” 2011, nr 9, s. 52. 
258 | Adam Mickiewicz University Law Review

Ustawodawca powinien podjąć kroki w celu pełniejszego zapewnienia kontradyktoryjności postępowania oraz faktycznej realizacji ustawowego obowiązku informowania przez organy procesowe uczestników postępowania o ich obowiązkach i uprawnieniach, w szczególności przez doprecyzowanie przepisów w zakresie doręczeń.

\section{Literatura}

Cieślak M., Polska procedura karna - podstawowe zatożenia teoretyczne, Warszawa 1984.

Daszkiewicz W., Proces karny. Częśí ogólna, Warszawa 1994.

Demendecki T., Glosa do postanowienia SN z dnia 21 lipca 2011 r., I KZP 7/11.

Doliwa A., Prawo cywilne - częś́ ogólna, Warszawa 2004.

Dudka K., Wptyw prawa karnego materialnego na ustawowa definicje pokrzywdzonego, [w:] Wspótzależność prawa karnego procesowego i materialnego, red. G. Arytmiak, Z. Ćwiąkalski, Warszawa 20099.

Durczak-Żochowska S., Glosa do postanowienia SN z dnia 21 lipca 2011 r., I KZP 7/11.

Grzegorczyk T., Kodeks postępowania w sprawach o wykroczenia. Komentarz, Warszawa 2012.

Grzegorczyk, J. Tylman, Polskie postępowanie karne, Warszawa 2011.

Jasiński W., Przedsiębiorca jako pokrzywdzony w procesie karnym na tle art. 49 par. 1 i 2 k.p.c., „Państwo i Prawo” 2012, nr 7.

Katner W.J., Podwójna czy potrójna podmiotowośc w prawie cywilnym, [w:] Rozprawy prawnicze. Ksiega pamiatkowa Profesora Maksymiliana Pazdana, red. L. Ogiegło, W. Popiołek, M. Szpunar, Kraków 2005.

Piaczyńska A., Przestępne przywtaszczenie sktadnika objętego wspólnym majątkiem wspólników, „Prokuratura i Prawo” 2011, nr 9.

Wolter A., Ignatowicz J., Stefaniuk K., Prawo cywilne. Zarys części ogólnej, Warszawa 2001.

Postanowienie SA w Katowicach z dnia 2 lipca 2008 r., II AKz 476/08, LEX nr 44711.

Postanowienie SN z dnia 10 marca 2006 r., IV CK 287/05, Lex nr 398357.

Postanowienie SN z dnia 21 lipca 2011 r., I KZP 7/11, LEX nr 852215.

Postanowienie SN z dnia 7 maja 2014 r., IV KK 364/13, http://www.sn.pl/sites/orzecznictwo/Orzeczenia3/Forms/Allltems.aspx [dostęp: 30.06.2016].

Uchwała SN z dnia 12 maja 1993 r., I KZP 6/93, LEX 20583.

Uchwała SN z dnia 15 września 1999 r., I KZP 26/99, OSNKW 1999, z. 11-12, poz. 69.

Uchwała SN z dnia 1 grudnia 1999 r., I KZP 26/99, LEX 38571.

Uchwała SN z dnia 21 października 2003 r., I KZP 29/03, LEX 81320.

Wyrok SA w Poznaniu z dnia 19 grudnia 2012 r., I Aca 1046/12, Lex nr 1264383. 
\begin{tabular}{l|l} 
Wykonywanie uprawnień przedsiębiorcy... & 259
\end{tabular}

\section{SUMMARY}

\section{Entrepreneur as an aggrieved party in criminal procedure}

The author analyzes the amendment of art. 49 of the Code of Criminal Procedure and presents several aspects of rights granted by the Code of Criminal Procedure to the entrepreneur. The article contains a review of previous problematic provisions of the CCP and describes the new course of reform, which granted the status of aggrieved party to state institutions and local government institutions. The author also emphasizes the role of delivery documents to entrepreneurs as they participate in criminal procedures as an aggrieved party. According to the new art. 304b CCP, written notice of the offense determines not only the elements of the offense but also specifies the identity of the victim by entering the address for correspondence, which in the course of further proceedings allows the authorities to take further procedural steps.

Keywords: entrepreneur, aggrieved party, criminal procedure, amendment of Article 49 Code of Criminal Procedure.

Katarzyna Prelińska, Gdańsk University, Faculty of Law and Administration, Jana Bażyńskiego 8, 80-309 Gdańsk, Republic of Poland, e-mail: kateprelinska@yahoo.co.uk. 